\title{
History of substance use and control in British Guiana ${ }^{1}$
}

\author{
Kellie Moss ${ }^{2}$, Deborah Toner ${ }^{3}$
}

\begin{abstract}
Whilst the impact of drugs on the culture of Caribbean societies and Indigenous populations is well documented, their role in maintaining influence over an ethnically diverse population and regulating labour productivity are frequently overlooked. In this paper we examine the use of drugs as a means of compelling and retaining labour in British Guiana during the nineteenth century. We also assess changes over time in how the colonial state managed concerns that the use of intoxicants threatened its control over the labouring population through licensing laws, carceral institutions and the criminalisation of certain drugs.
\end{abstract}

Keywords: Substance Use, British Guiana, Guyana, Psychotropic Substances, Intoxicants, Labour Productivity, Colonial Control, History, Opium, Cannabis, Alcohol.

Let they devotees extol thee, and they wondrous virtues sum, But the worst of names I'll call three, O thou hydra-monster Rum!

Pimple maker, visage bloater, health corrupter, idler's mate, Mischief breeder, vice promoter, credit spoiler, devil's bait.

(Ode to Rum, Bronkhurst, 1883)

\section{Introduction}

The control of psychoactive substances in British Guiana was established in the nineteenth and early twentieth centuries through varied local and international drug control initiatives related to spirits, opium, cannabis, and pharmaceutical products. As in other colonies, the first measures were implemented as a means of controlling the colonial population. In the initial stages of Dutch, and later British expansion in Demerara, Essequibo and Berbice psychoactive substances were introduced by settlers in an attempt to establish trade and relations of dependency with the Indigenous peoples (Burnett 2002, 3-40). In the process of expanding the colony's labour force after the abolition of slavery in 1833, the British aided in the introduction of a range of intoxicants from across the empire. Drugs such as alcohol, opium, and cannabis were used to overcome the physical discomfort of working for prolonged periods on the plantations and in forging social and spiritual relationships. The distribution, and in some cases production, of these substances played a crucial role in supressing emotional pain and compelling labour in conditions that might otherwise have been impossible (Jankowiak \& Bradburd 2003, 3-5).

\footnotetext{
1 This paper is based on research conducted for the ESRC-funded project Mental Health, Neurological and Substance Abuse (MNS) Disorders in Guyana's Jails: 1825 to the present day (award no. ES/S000569/1). This project is a collaboration between the University of Guyana and the University of Leicester, in partnership with the Guyana Prison Service. The project brings into dialogue researchers in History, Criminology, Sociology and Literature. It takes both a multi-disciplinary and interdisciplinary approach to key questions about the form, function, and experience of incarceration, encompassing inmates and the people who work with them. It encompasses both the British colonial period, and the era since Guyana's independence in 1966.

${ }^{2}$ Research Associate on the ESRC GCRF project Mental Health, Neurological and Substance Abuse Disorders in Guyana's Jails, 1825 to the present day, University of Leicester, Leicester, UK. Email: km345@leicester.ac.uk. ORCID: 0000-0002-2194-3935.

${ }^{3}$ Associate Professor of History, School of History, Politics and International Relations, University of Leicester, Leicester, UK. Email: dt151@le.ac.uk. ORCID: 0000-0003-3052-8642.
} 
Whilst the impact of drugs on the culture of Caribbean societies and Indigenous populations is well documented, their role in maintaining influence over an ethnically diverse population and regulating labour productivity are frequently overlooked. In this paper we examine the use of drugs as a means of compelling and retaining labour in British Guiana during the nineteenth century. We also assess changes over time in how the colonial state managed concerns that the use of intoxicants threatened its control over the labouring population through licensing laws, carceral institutions and the criminalisation of certain drugs.

\section{Encouraging Consumption as a Means of Control}

The introduction of drugs by traders and early settlers was an important part of efforts to induce Indigenous peoples to provide goods and labour. The production of psychoactive substances, especially cassava-based alcoholic drinks, was common among British Guiana's Indigenous population. Its consumption, however, was typically associated with periodic spiritual ceremonies and rites of passage, rather than as part of their daily diet or recreational habits (Smith 2005, 35-9, 176). For centuries, the Accaways, one of four nations who inhabited Upper Demerara, Mazaruni, and the Putaro districts, had produced a fermented beverage known as piwari for feasts (Bernau 1847, 42-3). Traditionally prepared for male consumption, missionaries noted that women would chew cassava bread into a pulp adding water until fermented. The men would then drink until they were in a state of 'beastly intoxication', or the trough (generally a canoe used for the purpose of fermentation) was empty (Duff 1866, 255). In addition to spiritual and celebratory occasions, the Indigenous population also utilised fermented beverages for medicinal purposes, such as reducing fever (quassia bark), stomach ache (mauby bark, also known as a 'decoction of woods'), and enriching the blood (sorrel plant). To motivate and organise the Indigenous population, colonial agents encouraged and fostered their use of stronger psychotropic substances, such as rum and brandy (Bernau 1847, 74-5). This rapid introduction of distilled spirits, in addition to European influence on habits of consumption, resulted in social dependencies that increasingly tied the Indigenous peoples to the colonial system (PP 1834 [617]; PP 1896 [C.7972 C. 7972-1 C.8106]). Although informal, the diversification and spread of intoxicants played a pivotal role in the political and economic shaping of the colony, and the colonial authorities increasingly managed access to drugs as a means to govern those on the fringes of society.

Legislation to criminalise certain uses of psychoactive substances was first introduced in British Guiana in 1838, following the termination of the apprenticeship system, through which the formerly enslaved were tied to their previous owners for a four-year period (18341838). ${ }^{4}$ In an attempt to retain power over them and thus avoid a decline in planation labour, the colonial government introduced numerous measures to restrict their mobility, including through an 1839 ordinance for the 'relief of the destitute poor' (TNA CO113/1, 1839). This act granted the Court of Policy (legislative council) the power to 'set to work' those unable to support themselves (TNA CO113/1, 1839). In accordance with the Act, anyone caught absconding, drunk, or introducing or attempting to introduce spiritous or fermented liquors into the workhouses could be sentenced to hard labour in prison for one month (TNA CO113/1, 1839). Yet, despite the introduction of this measure public disorder continued to be a concern

\footnotetext{
${ }^{4}$ In August 1833, the Slave Emancipation Act was passed, giving all enslaved peoples in the British empire their freedom. The act did not come into force until 1 August 1834. A system of apprenticeship was implemented alongside emancipation that required slaves to continue labouring for their former masters for a period of four to six years in exchange for provisions. Apprenticeship was abolished by each of the colonial assemblies in 1838, after pressure from the British public.
} 
primarily owing to the allocation of, and part payment of wages with, rum at the end of the working day (PP 1846 [691-I, 691-II, 691-III]). Interested in creating a captive consumer class, official tolerance regarding the issue of rum was traditionally favoured throughout the Caribbean. This sanctioned access to alcohol was a powerful incentive for enslaved labourers to actively engage in plantation work. Alcohol was integrated into creolized cultural practices that facilitated communication and interaction with the spiritual world, particularly in ceremonies honouring ancestral relationships and ritual healing practices. Enslaved labourers in British Guiana also probably valued rum for the social stimulus and camaraderie it could provide in group settings, as well as a source of physical and emotional release from the condition of slavery, as has been shown in other parts of the Caribbean and the US South (Smith 2004, 287-95; Smith 2005, 127-30, 157-63; Lussana 2016, 45-69). While planters often viewed such practices as a necessary form of release for enslaved labourers, there were increasing concerns among colonial authorities in the post-emancipation period, supported by a growing presence of temperance missionaries in the Caribbean, that intoxication was having adverse effects on the health, efficiency and productivity of the formerly enslaved (Smith 2005, 16973).

In an effort to reduce the harmful effects of the rum-based wage system on plantations, an ordinance to prohibit the issue, or part payment of wages with, spirituous liquor to plantation labourers was introduced in 1841 (TNA CO113/1, 1841). However, despite prohibiting its issue, the establishment of licensed liquor stores on estates was permitted. Drinking therefore, continued to be a concern in the country districts as many planters used these stores to circumvent the intention of the 1841 ordinance and maintain a cycle of debt peonage, in which various incentives were used to encourage labourers to spend wages in plantation liquor stores, thereby compelling them to return to work. For instance, rum shops were typically located near pay offices, where pay was issued at the end of the working week, and offered ready access to thirsty workers, with some liquor stores opening as early as 6.30 in the morning and others extending opening hours throughout the night (Smith 2005, 172). Despite attempts to coerce the formerly enslaved to remain on the plantations many continued to leave in favour of the villages and urban centres. As a result of this movement, and the vast number of spirit licenses being issued in towns, the consumption of spirits in urban areas increased as well (PP 1849 [297]).

\section{Efforts to Enhance Labour Productivity}

Following the abolition of slavery, to offset the emerging labour vacuum, plantation owners imported indentured contract labourers from Africa, Asia, and Europe (TNA CO113/1, 1841). The two main streams of immigration to the colony originated in India and China, where poverty and overpopulation forced large numbers to sign contracts of indenture (Gramaglia $2013,64)$. Under this scheme 238,939 indentured labourers were shipped from India between 1838 and 1917; and 13,533 from China between 1853 and 1884 (Roopnarine 2014, 158). These migrants were drawn from societies in which the cultivation and use of psychoactive substances, including fermented and distilled alcoholic drinks, opium and cannabis were widespread and common (Mills 1995, 179; Lee 2006 8-17; Smith 2005, 183-6; Fischer-Tiné 2014, 93-5; Wald 2018, 408-10). Colonial authorities estimated in 1858 that nearly two thirds of Chinese indentured migrants arriving in the Caribbean had at some point been addicted to opium (PP 1857-8 [525]). It is important not to take such observations at face value, given that images of opium addiction became embedded within imperial discourses about Chinese weakness over the course of the nineteenth century, but they can provide an indication of the commonality of opium use, as opposed to abuse (Dikötter, Laaman and Xun 2007, 19-38). Taken orally, as a medicine, opium left a bitter taste, but when smoked it released a sweet and 
pleasurable aroma, which rapidly became known for relieving boredom and anxiety (Dikotter, Laaman, and Xun 2004, 32). Similarly, in India the cultivation and consumption of Indian hemp, more commonly known as cannabis, was common in urban and rural contexts and throughout the many castes and classes (Mills 2009). In order to control and enhance the productivity of the labouring population colonial agents recognised this shift in consumption practices and sought to foster dependencies on opium and cannabis (Jankowiak \& Bradburd 1996, 717-720). Furthermore, plantation owners recognised that the anxiety and stress created by familial separation was partially subdued through the use of psychotropic substances. The lack of regulations regarding the sale and use of cannabis and opium also ensured these substances were initially accepted and, to a certain extent, even promoted as a means of enhancing labour productivity by plantation owners (Angrosino 2003, 102).

As the nineteenth century progressed official opposition to substance use first arose in recognition of the alleged debilitating effects and disobedience of substance users (PP 1857-8 [525]). These fears rapidly increased as the use of opium and cannabis spread among the different ethnic groups, threatening the authority of the colonial elite (PP 1871 [C.393, C.393I, C.393-II]; McDowall 1893, 630). Owing to the increased number of violent incidents being attributed to substance abuse, an ordinance to regulate the sale of opium and bhang (cannabis) was introduced to the colony in 1861 (TNA CO113/4, 1861). The primary focus of the act was to restrict the access of Indian and Chinese immigrants (TNA CO113/4, 1861). The evidence for this legislation, however, was based on little more than the casual observations of plantation owners (PP 1859 [31 31-I]). They suggested that labourers frequently shirked or performed less work due to intoxication (PP 1851 [624]; PP 1859 [31 31-I]). Critics used this evidence to feed into larger classifications and ideas about race and its connection to moral character (TNA CO 113/8, 1889; PP 1851 [624]; PP 1859 [31 31-I]). Debates regarding the use of psychotropic substances and their control are therefore rooted historically in much wider concerns related to colonial power structures, and the rights and privileges of the labouring population.

With recurrent concerns regarding the use of opium and cannabis in British Guiana, namely that excessive use left many 'unfit for work', rum continued to be encouraged by plantation owners as an alternative substance (PP 1871 [C. 393, C. 393-I, C. 393-II]). Unlike cannabis, and its indirect benefits as a labour enhancer, the planters directly profited from the production and distribution of rum (PP 1871 [C.458]). This was especially the case after the British Caribbean lost dominance of sugar markets by the middle of the nineteenth century and rum became a more reliably profitable export commodity than sugar (Smith 2005, 200-7). Efforts to solidify the planters' influence over the local spirit trade also became an integral part of its survival following the cessation of import duties in 1858 (PP 1858 [525]). The relaxation of excise duty on rum in 1868, from $\$ 2$ to 25 cents per gallon, assisted in reducing illegal trafficking and re-establishing rum as an affordable alternative to cheap imports (PP 1871 [C.458]). Stricter regulations on the retail spirit trade, which was predominantly made up of Portuguese migrant license holders, further strengthened the colonial elite's hold over it (PP 1871 [458]). Attempts to circumvent licensed premises, such as the production and consumption of coconut toddy's, a spiritous drink made by Indian immigrants from the fermented juice of the coconut tree, were quickly suppressed by their incorporation into the licensing laws (PP 1871 [C.393, 393-I, 393-II]; Bronkhurst 1883, 241).

A Royal Commission of enquiry set up to investigate the treatment of immigrants in 1870 drew attention to the extent and impact of drinking amongst the migrant workers, notably the misuse of estate hospitals to restrain and contain substance abusers (PP 1871 [393]). The consolidation of laws relating to indentured immigrants in 1873, in particular those connected 
to penalties for drunk and disorderly conduct, were a direct response to concerns regarding rising levels of insubordination and unrest amongst the labouring population, including strikes and riots in both British Guiana and Trinidad in the late 1860s (TNA CO 113/5, 1873; Smith $2005,184)$. While this disorder was largely a response of migrant workers to dreadful working conditions, plantation owners increasingly saw substance use as a form of covert resistance. By positing a need for these amendments, the plantation owners served to justify their increasingly repressive actions as they sought to dismiss those reluctant to work and avoid having to provide for their care. The increase in the number of charges related to those in breach of immigration laws, and the establishment of prisons at Fellowship (1868) and Suddie (1875) for the confinement of migrant workers, demonstrates the colonial elite's efforts to avoid an unruly and resistant population (Anderson, Ifill, Adams \& Moss, 2020).

Madness was added to this image of violence and disobedience in 1881 when the Medical Superintendent of the Public Lunatic Asylum in Berbice, Dr Robert Grieve, linked the use of psychoactive substances to insanity (McDowall 1893, 630; Grieve 1881, 82). In his monthly publication, The Asylum Journal, Grieve attempted to increase public awareness on a number of topics, including intemperance and narcotic use as causes of insanity (Grieve 1881, 132-135). Grieve identified numerous symptoms that he believed were a direct result of prolonged substance abuse. These included sleeplessness, incoherence, hallucinations, delusions, irritability, and erratic behaviour, effects which prohibited rather than encouraged labour (Grieve 1881, 84-85). In the wake of such concerns, in 1880 and 1889 amendments were added to the laws relating to the importation and sale of opium, and spirits in 1890 (TNA CO113/6, 1880; CO113/8, 1889; CO 113/8, 1890). The principal change was to tighten the regulations surrounding the manufacture and sale of these substances (TNA CO113/8, 1889; CO 111/451/96, 1889; CO 113/8, 1890). Links between substance abuse and criminality raised by the colony's Chief Medical Officer, Dr Thomas Ireland, added to these fears in 1893 as he claimed cannabis aroused 'acute mania with homicidal impulses' (McDowall 1893, 630). In highlighting these characteristics, the colonial authorities were able to dismiss the concerns and claims of many plantation labourers as the grievances of unstable and untrustworthy addicts (Gramaglia 2013, 76-77). By the 1890s the consumption of rum had significantly decreased amongst the labouring population, which no doubt reflects the abandoning of the rum-based wage system and the strict regulations regarding the manufacture and sale of spirits (Smith 2008, 176).

Internationally the drive to control psychoactive substances strengthened in 1912 at the Hague Opium Convention (TNA CO113/13, 1913; CO 111/584/163, 1912). Despite the lack of agreement amongst delegates, a discussion on cannabis had lasting repercussions for British Guiana as legislation was introduced to further regulate its importation and sale in 1913 (TNA CO113/13, 1913). Despite a lack of scientific consensus within these international debates, cannabis was designated from this point as a dangerous drug. An ordinance to regulate the importation and sale of opium was also introduced prohibiting its sale in a prepared form. In addition, the Act stated that all other forms of opium were to be administered by a registered medical practitioner (TNA CO 113/13, 1913). The cultivation, importation and dealing of cannabis and opium were officially criminalised in British Guiana following the introduction of the 1937 Dangerous Drugs Ordinance (TNA CO113/21, 1937). Later amendments followed Guyana's independence with the United Nations Convention against the Illicit Traffic in Narcotic Drugs and Psychotropic Substances in 1988, which required states to adopt measures to establish as a criminal offence any activity related to narcotic drugs (CARICOM Report 2018, 20-21). 


\section{Conclusion}

Throughout the history of British Guiana, the use and regulation of psychotropic substances has been determined by numerous factors, such as cultural expectations and economic motivations. The stimulating properties of these substances and their ability to establish and solidify bonds, whether social, economic, cultural or religious, has ensured their enduring and widespread demand from pre-colonisation to the present day. Within the dynamics of colonial labour regimes, drugs were routinely used as a reward to encourage productivity, but also led to cycles of debt and substance abuse, which helped to ensure the economically disadvantaged remained bound to their employers. As colonial institutions increasingly connected the use of intoxicants to insanity and criminality from the late nineteenth century, incarceration was also employed to manage the consumption habits, bodies, and social behaviours of labourers. While cannabis and opium became subject to increased restrictions and eventually criminalisation, alcohol remained legal and rum, especially, continued to be used as a labour incentive on plantations well into the twentieth century, due to its importance within the sugar plantation economy.

\section{References}

Anderson, C. Ifill, I. Adams, E. and Moss, K. (2020), 'Guyana's Prisons: Colonial Histories of Post-Colonial Challenges', The Howard Journal of Crime and Justice, 59, 3: 335-49.

Angrosino, M.V (2003) Rum and Ganja, Indenture, Drug Foods, Labor Motivation, and the Evolution of the Modern Sugar Industry in Trinidad, in W. R. Jankowiak, D. Bradburd, eds, Drugs, Labor, and Colonial Expansion. Tucson: University of Arizona Press.

Bernau, John Henry (1847) Missionary Labours in British Guiana: with remarks on the manners, customs and superstitious rites of the aborigines. London: John Farquhar Shaw.

Bronkhurst, H.V.P (1883) The Colony of British Guiana, and its Labouring Population. London: T. Woolmer.

Burnett, D. G (2002) “"It Is Impossible to Make a Step without the Indians": NineteenthCentury Geographical Exploration and the Amerindians of British Guiana', Ethnohistory, 49: 1, pp. 3-40.

CARICOM (2018) Regional Commission on Marijuana 2018, Waiting to ExhaleSafeguarding our Future Through Responsible Socio-Legal Policy on Marijuana. Caribbean Community: Secretariat.

Dikötter, F. Laaman, L. Xun, Z (2007) China, British Imperialism and the Myth of the "Opium Plague', in James H. Mills and Patricia Barton, eds, Drugs and Empire: Essays in Modern Imperialism and Intoxication, c. 1500-c.1930. Houndsmill: Palgrave, pp. 19-38.

Dikotter, F. Laamann, L. Xun, Z (2004) Narcotic Culture, A History of Drugs in China. London: Hurst \& Co. Ltd.

Duff, R. A. M (1866) British Guiana, Being Notes on a few of its Natural Productions, Industrial Occupations, and Social Institutions. Glasgow: Thomas Murray and Son.

Fischer-Tiné, Harald (2014) Liquid Boundaries: Race, Class, Alcohol in Colonial India, in Harald Fischer-Tiné and Jana Tschurenev, eds, A History of Alcohol and Drugs in Modern South Asia: Intoxicating Affairs. London: Routledge, pp. 89-115. 
Gramaglia, L (2013) Migration and Mental Illness in the British West Indies 1838-1900: The Cases of Trinidad and British Guiana, in Catherine Cox and Hilary Marland, eds, Migration, Health and Ethnicity in the Modern World. Basingstoke: Palgrave, pp. 61-82.

Grieve, Robert (2010) The Asylum Journal: conducted by the medical superintendent of the public lunatic asylum for British Guiana, Volume 1 (1881-1882) introduction by L. Gramaglia. Guyana: The Caribbean Press.

Jankowiak, W. R. Bradburd, D (2003) Drugs, Desire, and European Economic Expansion, in W. R. Jankowiak, D. Bradburd, eds, Drugs, Labor, and Colonial Expansion. USA: University of Arizona Press, pp. 3-30.

UK House of Commons Parliamentary Paper [PP]:

- 1834 [617] Papers relating to Aboriginal Tribes of N. America, New South Wales, Van Diemen's Land, and British Guiana: Despatch from Colonial Secretary (Viscount Goderich) Frederick John Robinson, to Governor Benjamin D’Urban, 17 February 1832.

-1837 [425] Report from the select Committee on Aborigines in British Settlements: South America, Comments from the Prime Minister (Lord Goderich) Frederick John Robinson, 26 June 1837.

- 1846 [691-I, 691-II, 691-III] Returns relating to labouring population in British colonies: Enclosure 2, Mayor of Georgetown, John Croal, observations relative to drunkenness, in a copy of a despatch from Governor Henry Light to Secretary of State, Edward Smith Stanley (Lord Stanley), 2 July 1845.

- 1849 [297] Select Committee on Ceylon and British Guiana: Consolidated Return, half year ending $31^{\text {st }}$ December 1848, Table C, Colony of British Guiana, 7 February 1849, J. H. Goodman, Acting Circuit Stipendiary Magistrate.

- 1851 [624] Despatches on Condition of Sugar-growing colonies: Part 1. British Guiana, subenclosure 1, to enclose 2, in No. 70, Protector of Emigrants, 16 December 1850.

- 1857-8 [525] Emigration. Emigration from China to British Guiana and Trinidad. Copies of letters addressed by members of the West India Committee to the Secretary of State for the Colonies, on the subject of emigration from China to the colonies of British Guiana and Trinidad, and of documents connected therewith; also, of replies from the Colonial Secretary and the Emigration Commissioners: Report on the State of Disease on board the Ship "Kitty Simpson", during her recent voyage from Swatao to Havana, from Thomas H. Somerville, Surgeon on the Kitty, 18 March 1858.

- 1859 [31, 31-I] Correspondence between Colonial Office and Governors of W, Indian Colonies and Mauritius, with respect to Conditions of Labouring Population and Supply of Labour (Part I. British Guiana; Jamaica; Trinidad). Letter from Acting Stipendiary Magistrate, L. G. Tucker to the Acting Government Secretary, J. Gardiner Austin, 10 December 1857.

- 1871 [C. 393, C. 393-1, C.392-II] Report of the commissioners appointed to enquire into the treatment of immigrants in British Guiana: Commission Report Mr Des Veux to Colonial Secretary, Granville Leveson-Gower (Earl Granville), 25 December 1869.

- 1871 [C.458] Correspondence on Complaints of Portuguese Residents in British Guiana: Enclosure No. 7, Governor John Scott to the Colonial Secretary, John Wodehouse (Earl of Kimberley), 26 April 1871. 
- 1896 [C. 7972 C. $7972-1$ C. 8106] Documents and correspondence relating to question of boundary between British Guiana and Venezuela: Appendix No. II, Enclosure No.6, despatch from Acting Governor Codd to Earl Bathurst, 26 September 1818, Instruction for the postholders with the Indians in Essequebo and Demerary, P. F. Ginne, Secretary.

Jankowiak, W. Bradburd, D (1996) Using Drug Foods to Capture and Enhance Labor Performance: A cross cultural perspective, Current Anthropology, 37.4, pp. 717-720.

Lee, Peter (2006) Opium Culture: The Art and Ritual of the Chinese Tradition. Vermont: Park Street Press.

Lussana, Sergio (2016) My Brother Slaves: Friendship, Masculinity and Resistance in the Antebellum South. Lexington: University Press of Kentucky.

McDowall, T.W (1893) Section of Psychology, Insanity from the Abuse of Indian Hemp, in The British Medical Journal, vol. 2, No. 1707, 16 September 1893, pp. 618-630.

Mills, J (2009) Cannabis and the Cultures of Colonialism: Government, Medicine, ritual and pleasures in the history of an Asian drug (c. 1800 - c. 1895),' Zeitenblicke, 9 (3). Available at http://www.zeitenblicke.de/2009/3/Abstractseng/index_html (Accessed on 1 April 2020).

Mills, J (1995) 'Globalising Ganja: The British Empire and International cannabis traffic c. 1834 to c. 1939' in J. Goodman, P. Lovejoy, and A. Sherratt, eds, Consuming Habits, Global and Historical Perspectives on How Cultures Define Drugs. London: Routledge, pp. 178-93.

Roopnarine, L (2014) Resistance and Adaptation among Indentured Indian Labourers in British Guiana during Indentureship, in M. S. Hassankhan, B. V. Lal, D. Munro, eds, Resistance and Indian Indenture Experience, Comparative Perspectives. New Delhi: Manohar Publishers, pp. 157-82.

Smith, Frederick (2004) Spirits and Spirituality: Enslaved Persons and Alcohol in West Africa and the British and French Caribbean, The Journal of Caribbean History, 38:2, pp. 279-309.

Smith, Frederick (2005) Caribbean Rum: A Social and Economic History. Gainesville: University Press of Florida.

Rayner, T. Nunan, J. J, (1916) 'South Atlantic,' Journal of the Society of Comparative Legislation, vol. 16, pp. 183-193.

TNA [The National Archives]:

- CO 111/451/96: Ordinance 4 of 1889, Despatch from Governor Jenico Preston, (Viscount Gormanston) to Colonial Secretary Henry Holland, (Baron Knutsford), 25 March 1889.

- CO 111/584/163: Convention, Opium, Morphia \& Cocaine, Response to circular despatch from Government Secretary Charles Cox to Colonial Secretary Lewis Harcourt, 21 May 1912.

- CO 113/1/15: An ordinance for the relief of the destitute poor in British Guiana, 1839.

- CO 113/1/4: An ordinance to regulate and encourage immigration into British Guiana, 1841.

- CO 113/1/9: An ordinance to regulate and carry into effects the licensing and conducting of retail spirit shops in the rural districts; to prevent evasions of the tax on rum, and to prohibit the issuing of rum by unlicensed persons in British Guiana, 1841.

- CO 113/4/22: An ordinance to regulate the sale of opium and bhang, 1861. 
- CO 113/5/7: An ordinance to consolidate and amend the law relating to immigrants, 1873.

- CO 113/6/26: An ordinance to amend the law relating to the importation and sale of opium, 1880 .

- CO 113/8/4: An ordinance to amend the law relating to the importation and sale of opium, 1889.

- CO 113/8/24: An ordinance to consolidate and amend the laws relating to the manufacture, storage, conveyance, and sale of spirits, 1890.

- CO 113/13/29: An ordinance to regulate the importation and sale of preparations of Indian Hemp, 1913.

- CO 113/13/30: An ordinance to give effect to the measures decided upon in the International Opium Convention signed at the Hague on the $23^{\text {rd }}$ day of January 1912 , and regulate the importation, exportation, storage and disposal of opium, morphine, cocaine and similar drugs in this colony, 1913.

- CO 113/21/10: An Ordinance to regulate the importation, exportation, production, manufacture, sale and use of Opium, 1937.

Wald, Erica (2018) Governing the Bottle: Alcohol, Race and Class in Nineteenth-Century India, Journal of Imperial and Commonwealth History, 46:3, pp. 397-417. 